ROCZNIKI NAUK PRAWNYCH

Tom XXXI, numer $1-2021$

DOI: https://doi.org/10.18290/rnp21311-6

\title{
RYS HISTORYCZNY KLAUZULI PORZĄDKU PUBLICZNEGO W ARBITRAŻU HANDLOWYM W PRAWIE POLSKIM DO OKRESU PRL WŁĄCZNIE*
}

\begin{abstract}
WSTĘP
W polskiej literaturze istnieją jedynie trzy monografie odnoszące się do materii klauzuli porządku publicznego, a mianowicie: Mieczysława Sośniaka pt. Klauzula porzadku publicznego w prawie międzynarodowym prywatnym (Warszawa 1961), Macieja Zachariasiewicza pt. Klauzula porzadku publicznego jako instrument ochrony materialnoprawnych interesów i wartości fori (Warszawa 2018) oraz moja rozprawa doktorska pt. Klauzula procesowego porzadku publicznego $w$ arbitrażu handlowym $w$ prawie polskim na tle innych systemów prawnych (Warszawa 2019). Poza tymi opracowaniami w literaturze przedmiotu nie zajmowano się w sposób kompleksowy kwestią historii klauzuli porządku publicznego w ogólności, a w szczególności w arbitrażu handlowym. Celem artykułu jest próba analizy tej instytucji prawnej do czasów PRL. Rola sądownictwa arbitrażowego jest znaczna w obecnym obrocie gospodarczym w Rzeczpospolitej Polskiej i z każdym dniem rośnie, zatem temat niniejszy ma zasadnicze znaczenie nie tylko naukowe, ale i praktyczne.
\end{abstract}

\section{POCZĄTKI POJĘCIA KLAUZULI PORZĄDKU PUBLICZNEGO}

Klauzula porządku publicznego jest nierozerwalnie związana z sądownictwem arbitrażowym. Wyrażono pogląd, że sądownictwo polubowne, a tym

Dr KAROL RYszKowSKI - adiunkt, Katedra Prawa Cywilnego, Gospodarczego i Prywatnego, Międzynarodowy Instytut Prawa Uniwersytetu Ekonomicznego w Krakowie; ul. Rakowicka 27, 31-510 Kraków; e-mail: ryszkowskikarol@gmail.com; ORCID: https://orcid.org/0000-0003-2744-3533.

* Publikacja została dofinansowana ze środków subwencji przyznanej Uniwersytetowi Ekonomicznemu w Krakowie. 
samym klauzula porządku publicznego, jest tak stare jak historia ludzkości oraz znacznie starsze od sądownictwa powszechnego. W komedii antycznej Sad rozjemczy (Epitrepontes) z przełomu IV i III wieku p.n.e. Menander opisał spór pomiędzy dwoma niewolnikami, który zostaje poddany pod rozstrzygnięcie arbitrażu ad hoc. Pośród przewijających się w sztuce elementów pojawia się także odesłanie do zasad porządku publicznego ${ }^{1}$, a więc zarówno sądownictwo arbitrażowe, jak i instytucja klauzuli porządku publicznego były już znane fundamentalnemu dla całego porządku prawnego, w tym polskiemu, systemowi prawa - prawu rzymskiemu.

Instytucja arbitrażu występuje już w starożytnych systemach prawnych Indii i Egiptu, a następnie w Digestach Justyniana ${ }^{2}$, zaś dzięki recepcji prawa rzymskiego na Zachodzie i prawa rzymsko-bizantyjskiego ${ }^{3}$ na Wschodzie - w wielu innych systemach prawnych ${ }^{4}$, zwłaszcza w Szwajcarii i Grecji.

\section{HISTORIA KLAUZULI PORZĄDKU PUBLICZNEGO W PRAWIE PRYWATNYM MIĘDZYNARODOWYM DO OKRESU MIĘDZYWOJENNEGO}

W myśl rzymskiej paremii Mater est semper certa (Matka zawsze jest pewna) znamy „matkę” współczesnej klauzuli porządku publicznego w arbitrażu handlowym, jest nią prawo prywatne międzynarodowe. Ponadto, ze względu na okres zaborów część z prezentowanych poniżej koncepcji bezpośrednio oddziaływała na prawodawstwa obowiązujące na ziemiach polskich. To właśnie w tej dziedzinie prawa zapoczątkowano naukową refleksję nad klauzulą porządku publicznego. Przedmiotem tej dziedziny jest stosowanie norm

\footnotetext{
${ }^{1}$ P. NowACZYK, Sąd Arbitrażowy przy KIG na tle innych instytucji arbitrażowych, Court of Arbitration at the Polish Chamber of Commerce compared to other arbitral institutions, „Biuletyn Arbitrażowy" 2008, nr 7, s. 65.

${ }^{2}$ M. ZIELIŃSKI, Klauzula porządku publicznego przy uznawaniu $i$ wykonywaniu wyroków w międzynarodowym arbitrażu handlowym w świetle systemów prawnych Polski, Niemiec, Szwajcarii, oraz porządku prawnego Unii Europejskiej (Prace laureatów konkursu na najlepszą pracę magisterską dotyczącą problemów sądownictwa polubownego i mediacji im. prof. dr. hab. Jerzego Jakubowskiego), Warszawa: C.H. Beck 2003, s. 232.

3 „Termin ten został wprowadzony przez Karla Eduarda Zachariä von Lingenthal dla określenia prawa rzymskiego, które zostało skodyfikowane na terenie Cesarstwa Bizantyńskiego". K. RYszKOWSKI, P. PROKOCKI, Losy prawa rzymskiego na Wschodzie od śmierci Justyniana Wielkiego do upadku Cesarstwa Bizantyjskiego, „Edukacja Prawnicza” 2020, nr 1, s. 12.

${ }^{4}$ K. RYSZKOWSKI, Klauzula procesowego porzadku publicznego $w$ arbitraż handlowym w prawie polskim na tle innych systemów prawnych, Warszawa: C.H. Beck 2019, s. 9.
} 
merytorycznych obcego prawa w określonych przez prawo kolizyjne państwa forum sytuacjach. Różne systemy prawne mogą przyjmować całkowicie inne rozwiązania, a więc istnieje zagrożenie, że sąd państwa forum będzie zmuszony w ustalonych sytuacjach do wydania orzeczenia na podstawie norm prawa obcego, które są uznawane w państwie sądu za rażąco niesprawiedliwe. Żeby zapobiec takiemu stanowi rzeczy, zaczęto stosować klauzulę porządku publicznego. Mechanizm i konstrukcja tej instytucji prawnej w trakcie rozwoju prawa międzynarodowego prywatnego ulegały zmianom, a później również innych dziedzin prawa ${ }^{5}$.

W literaturze włoskiej można spotkać się z poglądem, że średniowieczne statuta odiosa były pierwowzorem klauzuli porządku publicznego ${ }^{6}$, tak jak kolejna instytucja statuta favorabilia Bartolusa de Saxoferrato ${ }^{7}$.

Mieczysław Sośniak łączy początki doktryny porządku publicznego z pierwszymi nowoczesnymi koncepcjami terytorialistycznymi, to jest z ideą suwerenności, czyli w głównej mierze z holenderską szkołą statutową ${ }^{8}$. Niezależnie od roli Johannesa Voeta, to inny przedstawiciel tej szkoły - Ulryk Huber $\mathrm{w}$ trzecim aksjomacie pisał o uszczerbku w prawach i o władzy terytorialnego suwerena oraz jego poddanych, które wynika ze stosowania prawa obcego. W tym aksjomacie tkwi zapowiedź późniejszych ograniczeń w stosowaniu prawa obcego z prawie takim samym uzasadnieniem ${ }^{9}$. Należało więc zabezpieczyć się przed niebezpieczeństwem wynikającym z używania prawa obcego. W szczególnie ważnych punktach dla interesów wewnętrznych państwa zastrzeżenie to miało ochraniać porządek publiczny przed obcą ingerencją ${ }^{10}$.

Koncepcje zbliżone i zapowiadające pojęcie porządku publicznego powstają w krajach bardzo rozwiniętych gospodarczo w XVIII wieku, to jest we Francji i w Holandii. Francuski prawnik Jean Bouhier mówił o causes

${ }^{5}$ N. Rycko, Stosowanie klauzuli porządku publicznego przez Polski Sąd Państwowy w sprawach dotyczacych arbitrażu (Prace laureatów konkursu na najlepszą pracę magisterską dotyczącą problemów sądownictwa polubownego i mediacji im. prof. dr. hab. Jerzego Jakubowskiego), edycja piąta, Warszawa: C.H. Beck 2012, s. 205.

${ }^{6}$ M. SoŚNIAK, Klauzula porządku publicznego w prawie międzynarodowym prywatnym, Warszawa: Państwowe Wydawnictwo Naukowe 1961, s. 6.

${ }^{7}$ K. Bagan-Kurluta, Prawo prywatne międzynarodowe, Warszawa: C.H. Beck 2006, s. 124. Zob. szerzej na temat statuta odiosa, statuta favorabilia i Bartolusa de Saxoferrato - M. ZACHARIASIEWICZ, Klauzula porzadku publicznego jako instrument ochrony materialnoprawnych interesów $i$ wartości fori, Warszawa: C.H. Beck 2018, s. 6.

${ }^{8}$ M. SOŚNIAK, Klauzula, s. 6.

${ }^{9}$ Tamże, s. 6-7.

${ }^{10}$ Tamże, s. 10. 
publiques, które miały dotyczyć dobrych obyczajów oraz wspólnego dobra i należało je stosować w każdym przypadku bez wyjątku ${ }^{11}$.

Na przełomie XVIII i XIX wieku we Francji bardzo widoczna była społeczno-gospodarcza geneza pojęcia porządku publicznego, stanowiącego instrument ochrony interesu burżuazji ${ }^{12}$. Na okres wczesnego kapitalizmu przypadają pierwsze próby bliższego określenia klauzuli porządku publicznego ${ }^{13}$. Porządek publiczny, który stanowił już u schyłku XVIII wieku we Francji pewne pojęcie społeczno-polityczno-gospodarcze, znalazł się w Kodeksie Napoleona - pierwszej kodyfikacji młodego kapitalizmu. W ramach Kodeksu Napoleona klauzula porządku publicznego strzegła praworządności, oznaczała przeciwieństwo anarchii, ogół organizacji prawnej społeczeństwa, odnosiła się do wszystkich ustaw i patronowała prawnej harmonii systemu. Zgodnie z tak pojmowanym porządkiem, był on najwyższą zasadą prawną, a nie należał do konkretnej dziedziny prawa ${ }^{14}$. Pojęcie ordre public po raz pierwszy zostało użyte w komentarzu do Kodeksu Napoleona przez francuskiego deputowanego Boulaya. Za pomocą tego pojęcia określa się klauzulę porządku publicznego w prawie francuskim ${ }^{15}$.

Kształtujący się kapitalizm posługiwał się w wewnętrznym obrocie elementami zaufania i pewności prawa, a więc obrona przeciw niekorzystnemu stosowaniu obcego prawa musiała mieć trwały oraz pewny charakter. Po pierwsze - musiała nawiązywać do ustaw uznanych przez ustawodawcę za wybitnie doniosłe dla dobra ogólnego. Po drugie - ograniczenia powinny być możliwie przewidywalne i ściśle sformułowane, by nie szkodzić rozwijającej się wymianie towarowej. Na tym poziomie rozwoju ochrona interesów własnych nie była jeszcze połączona z klauzulami generalnymi. Za ogólnym zastrzeżeniem porządku publicznego miały stać, uchwytne i treściwe, ustawy ${ }^{16}$.

Teoria Josepha Story'ego w Stanach Zjednoczonych i teoria Friedricha Carla von Savigny'ego w Europie czyniły zadość tej potrzebie czasu. Obydwie teorie zbudowały system norm kolizyjnych i obie rozstrzygały zagadnienie ograniczeń w stosowaniu prawa obcego w tymże systemie ${ }^{17}$. F.C. von Savigny twierdził, że prawo obce nie powinno być zastosowane w przypadkach, gdy

\footnotetext{
11 Tamże, s. 7.

12 Tamże.

${ }^{13}$ J. GiLAS, Prawo prywatne międzynarodowe, Warszawa: Wydawnictwo Prawnicze LexisNexis 2002, s. 99.

${ }^{14}$ M. SOŚNIAK, Klauzula, s. 8.

${ }^{15}$ M. ZIELIŃSKI, Klauzula, s. 232.

${ }^{16}$ M. SOŚNIAK, Klauzula, s. 10.

${ }^{17}$ Tamże.
} 
prawo to zawiera nieznane lex fori instytucje, albo dana materia regulowana jest bezwzględnie wiążącą ustawą, która stanowi element porządku prawnego lex fori i wymuszającą swoją właściwość bez względu na wskazanie prawa ${ }^{18}$. W późniejszej teorii niemieckiej w jedną zasadę przekształciły się oba wyżej wymienione przypadki ograniczające zastosowanie obcego prawa ${ }^{19}$. W zarysie, który przedstawił Savigny, jest widoczna cała dziewiętnastowieczna problematyka klauzuli porządku publicznego. Na tym etapie nauka przechodzi z ogólnych ograniczeń międzynarodowej kurtuazji na obszar konkretnych ustaw krajowych, wyłączających a limine zastosowanie obcego prawa na podstawie publica utilitas ${ }^{20}$.

Przykładem rozwiązania normatywnego, które reprezentowało teorię i weszło do kanonu nauki prawa międzynarodowego prywatnego, były włoskie przepisy o ogłaszaniu, wykładni i stosowaniu ustaw z 1865 r., w tym art. 12 tych przepisów ${ }^{21}$, wprowadzający wyłączną właściwość ustaw zakazujących dotyczących osób, rzeczy i czynności, a także ustaw związanych z porządkiem publicznym lub dobrymi obyczajami ${ }^{22}$ (włos. l'ordine publicco et il buon costume). Stąd też instytucję tę nazywa się klauzulą porządku publicznego (ang. public policy; franc. ordre public; niem. Öffentliche Ordnung) lub podobnymi określeniami. W nauce niemieckiej można także spotkać się z pojęciem klauzuli zastrzegającej ${ }^{23}$ (niem. kollisionsrechtliche Vorbehaltsklausel ${ }^{24}$ ).

Nowa szkoła włoska odsunęła teorię Friedricha Carla von Savigny'ego w drugiej połowie XIX wieku ${ }^{25}$. Szkoła Pasquale Stanislao Manciniego stworzyła ogólną kategorię porządku publicznego i dobrych obyczajów, z którymi sprzeczność uniemożliwiała prawu obcemu zastosowanie w danym kraju ${ }^{26}$. Dla Manciniego porządek publiczny stanowił wyłom od zasady personalizmu, uzasadnionym względami specjalnymi natury ogólnej. W ich skład wchodziły zasady: społeczne, polityczno-ekonomiczne i moralności nieograniczające się do danego narodu. Ich doniosłość uzasadniała objęcie cudzoziemców ustawami,

${ }^{18}$ K. Bagan-Kurluta, Prawo, s. 124.

${ }^{19}$ M. SoŚnIAK, Klauzula, s. 13.

${ }^{20}$ Tamże, s. 12.

${ }^{21}$ M. CZEPELAK, Umowa międzynarodowa jako źródto prawa prywatnego międzynarodowego, Warszawa: Wolters Kluwer Polska 2008, s. 499.

22 J. Gilas, Prawo, s. 99.

${ }^{23}$ N. RYCKO, Stosowanie klauzuli, s. 206.

${ }^{24}$ M. PAzDAN, Prawo prywatne międzynarodowe, Warszawa: Wydawnictwo Prawnicze LexisNexis 2012, s. 77.

${ }^{25}$ M. SOŚNIAK, Klauzula, s. 13-14.

${ }^{26}$ M. SoŚnIAK, Prawo prywatne międzynarodowe, Katowice: Wydawnictwo Uniwersytetu Śląskiego 1991, s. 86. 
które je zawierały. W ramach tych ustaw zaliczano te z prywatnoprawnych, które chroniły porządek ekonomiczny lub moralny, i ustawy z całej dziedziny prawa publicznego ${ }^{27}$. Wedle tej szkoły porządek publiczny stanowi odblask zasady suwerenności, czego następstwem jest terytorialność skutków pewnych ustaw. Savigny wychodził od prawa wewnętrznego i pewnej grupy ustaw w ramach tego prawa, podczas gdy Mancini od zasady narodowości ${ }^{28}$.

Kolejni przedstawiciele tej szkoły rozwijali cechę podstawowości zasad porządku publicznego, która została wprowadzona na stałe już do doktryny tej instytucji ${ }^{29}$.

Rezultatem szkoły włoskiej były dwa czynniki porządku publicznego: merytoryczny i metodyczny. Pierwszy wskazywał na wagę społeczno-politycznych momentów. Znaczny dorobek posiadali w kształtowaniu tego czynnika Francuzi, którzy dzięki rozbudowie ogólnych kryteriów charakteryzowali całą grupę politycznych lub wyłączających ustaw. Z kolei czynnik metodyczny sprowadzał materię porządku publicznego do kwalifikowania własnych wyłączających ustaw wewnętrznych ${ }^{30}$.

W ten sposób powstały dwa ujęcia klauzuli porządku publicznego. Jedno wychodziło od wewnątrz, gdyż nie uznawało obcej właściwości w materii, w której własne prawo wypowiadało się w sposób kategoryczny. Drugie natomiast nawiązywało do pojęć ogólnych (ponadnarodowych i ponadpaństwowych) oraz badało pod kątem widzenia tych pojęć prawo obce ${ }^{31}$. Oba prowadziły do przerostu klauzuli porządku publicznego. W pierwszym z ujęć przerost był powodowany poszerzaniem zakresu norm imperatywnych a limine wyłączających stosowanie przepisów obcych. Przerosty bazujące na drugim ujęciu powstawały poprzez nadawanie porządkowi publicznemu i dobrym obyczajom treści, która jest korzystna dla interesów własnego prawa ${ }^{32}$.

Te dwa ujęcia doprowadziły do przekształcenia się zasad ponadpaństwowych w szereg autonomicznych, odróżniających się kręgów ustawodawczych, które posługiwały się z góry ustalonymi ustawami wyłączającymi dostosowanymi do potrzeb wewnętrznych danego kraju. Z tego względu Mieczysław Sośniak koncepcję ustaw wyłączających i szkołę włoską określa jednym

\footnotetext{
${ }^{27}$ M. SoŚNIAK, Klauzula, s. 14.

28 Tamże, s. 15.

${ }^{29}$ Tamże, s. 14.

${ }^{30}$ Tamże, s. 17.

${ }^{31}$ M. SoŚniaK, Prawo prywatne, s. 86.

32 Tamże, s. 86-87.
} 
mianem - koncepcji autonomicznej ${ }^{33}$. Była to koncepcja eklektyczna, ponieważ zapożyczone z Pasquale Stanislao Manciniego ogólne zasady porządku publicznego dostosowano do ustaw bezwzględnie obowiązujących wyjętych $\mathrm{z}$ teorii Friedricha Carla von Savigny' go $^{34}$.

Już w okresie międzywojennym zwracano uwagę na przesadne poglądy o przepaści pomiędzy romańskim a niemieckim ujęciem klauzuli ${ }^{35}$. Różnice między francuskim lois d'ordre public a niemieckim Prohibitivgesetze były mniejsze, aniżeli przypuszczali zwolennicy ich wyraźnego przeciwstawienia. W obydwu przypadkach istniała kategoria $\mathrm{z}$ góry ustalonych ustaw (bez badania treści i skutków oddziaływania obcych przepisów), które a limine bezwzględnie wyłączały stosowanie prawa obcego. Różnice można było znaleźć w naturze kryteriów, jakim na terenie niemieckim i francuskim się posługiwano. W porządku germańskim były one formalne (w szczególności cel i treść ustawy), natomiast w porządku francuskim - raczej materialne dotyczące doniosłości społecznej i państwowej omawianych ustaw. Ponadto tej różnicy nie sposób wykazać u wszystkich przedstawicieli obydwu zaprezentowanych odłamów koncepcji autonomicznej, a często pojawiała się ona dopiero na późniejszym etapie rozwoju ${ }^{36}$.

U podstaw teorii Prohibitivgesetze tkwiła zamienność pomiędzy prawem wewnętrznym a prawem międzynarodowym prywatnym ${ }^{37}$. Spowodowała ona uznanie art. 6 Kodeksu Napoleona za naczelną regułę porządku publicznego w prawie międzynarodowym prywatnym, pomimo że w zamierzeniu twórców przepis ten nie odnosił $\mathrm{w}$ ogóle do tej materii ${ }^{38}$. Z wewnętrznego charakteru ustaw wyciągano wniosek o ich funkcji kolizyjnej. Przy tym pomijano całkowicie odmienną rolę pojęcia porządku publicznego w prawie wewnętrznym aniżeli na gruncie prawa prywatnego międzynarodowego. Na terenie prawa prywatnego międzynarodowego chodzi o odmowę zastosowania prawa obcego, podczas gdy w prawie wewnętrznym to norma, której nie można wyłączyć oświadczeniami stron. Podczas krytyki Prohibitivgesetze M. Sośniak podaje dalej, że uznanie wszystkich przepisów iuris cogentis za wyłączające z reguły

\footnotetext{
${ }^{33}$ M. SOŚNIAK, Klauzula, s. 19.

${ }^{34}$ Tamże, s. 20.

${ }^{35}$ F. KAHN, Abhandlungen zum internationalen Privatrecht, München: Verlag Duncker \& Humblot 1928, s. 199

${ }^{36}$ M. SoŚnIAK, Klauzula, s. 20.

37 Tamże, s. 22.

${ }^{38}$ Tamże, s. 23.
} 
prawo obce skutkowałoby całkowitym unicestwieniem prawa prywatnego międzynarodowego ${ }^{39}$.

Koncepcja ta wywarła wpływ na ogólne i zwięzłe ujęcie klauzuli porządku publicznego, bez konieczności tworzenia zbioru ustaw wyłączających ${ }^{40}$. Koncepcja porównawcza doprowadzała jednak do oceny treści i wyłączenia prawa obcego ze względu na jego sprzeczność z treścią ustawodawstwa państwa forum, natomiast nie z uwagi na sprzeczność skutków zastosowania prawa obcego z porządkiem publicznym forum ${ }^{41}$.

\section{HISTORIA KLAUZULI PORZAQDKU PUBLICZNEGO}

W OKRESIE MIĘDZYWOJENNYM I OKRESIE PRL W POLSKIEJ DOKTRYNIE

W historii nauki prawa prywatnego międzynarodowego były okresy, w których istniała obawa, iż klauzula porządku publicznego całkowicie uniemożliwi funkcjonowanie systemu norm kolizyjnych, ponieważ - jak podkreślano zastosowanie obcego systemu da się w najróżniejszych wypadkach wyłączyć poprzez powołanie się na tę klauzulę ${ }^{42}$. W celu prezentacji takiego okresu, lepszego poglądu oraz pełnego zastosowania wykładni historycznej należy także przedstawić poglądy na klauzulę porządku publicznego w nauce prawa prywatnego międzynarodowego w okresie PRL:

[Nauka] prawa międzynarodowego prywatnego krajów socjalistycznych, opierając się na zasadach pokojowego współistnienia i pokojowej współpracy narodów bez względu na ich ustrój polityczny i społeczno-gospodarczy, ich ideologię i tradycje kulturowe, w tym tradycje prawne, uważa stosowanie klauzuli porządku publicznego za instrument, który należy stosować absolutnie wyjątkowo, w sytuacjach, gdy jest to niezbędne z punktu widzenia krajowej polityki społecznej. Klauzula ta powinna być traktowana nie jako normalne narzędzie prawa kolizyjnego, lecz jako ostateczność, jako ultimum remedium, jako „klapa bezpieczeństwa”³.

\footnotetext{
39 Tamże, s. 22.

40 Tamże, s. 47.

${ }^{41}$ Tamże, s. 51.

${ }^{42}$ M. SoŚniAK, B. WALASZeK, Zarys prawa prywatnego międzynarodowego, Warszawa: Państwowe Wydawnictwo Naukowe 1973, s. 121.

${ }^{43}$ J. JAKUBOWSKI, Prawo międzynarodowe prywatne. Zarys wyktadu, Warszawa: Państwowe Wydawnictwo Naukowe 1984, s. 62-63.
} 
Skutkiem takich zapatrywań było wydzielenie dwóch porządków publicznych, a więc państw kapitalistycznych i państw socjalistycznych. Na podstawie ówczesnego orzecznictwa SN zrekonstruowano stanowisko o niedopuszczalności stosowania klauzuli porządku publicznego w stosunkach między Polską Rzeczpospolitą Ludową a innymi państwami socjalistycznymi, które zawarły z PRL-em umowy o pomocy prawnej. W literaturze uzasadniano ten pogląd, podnosząc, iż klauzula porządku publicznego to wyraz nieufności w stosunkach pomiędzy krajami kapitalistycznymi i między krajami socjalistycznymi a krajami kapitalistycznymi. Twierdzono, że podstawowe zasady porządków prawnych państw socjalistycznych mają te same założenia ideologiczne, a więc między fundamentalnymi zasadami tych państw nie występują na tyle duże różnice, żeby orzeczenia oparte na prawie jednego z państw socjalistycznych nie dało się pogodzić z podstawowymi zasadami drugiego państwa socjalistycznego ${ }^{44}$.

Pojawiły się wypowiedzi, które dopuszczały powoływanie się na klauzulę porządku publicznego w stosunkach między państwami socjalistycznymi. Stanowisko to było uzasadniane istnieniem klauzuli porządku publicznego niezależnie od jej pominięcia czy też jej regulacji expressis verbis $\mathrm{w}$ danym systemie prawnym i możliwością zaistnienia wyjątkowych wypadków, w których interwencja tej instytucji prawnej będzie konieczna w niesłychanie rzadkich wypadkach, pomimo tożsamych albo bardzo podobnych założeń ideologicznych poszczególnych państw socjalistycznych ${ }^{45}$.

Wraz ze zmianami politycznymi, społecznymi i gospodarczymi w wielu państwach świata stosowanie klauzuli porządku publicznego wróciło do normalnych proporcji. Zrozumiano zagrożenia wynikające z jej ekstensywnego stosowania, w tym również dla stosującego. Próbowano ograniczyć używanie tej instytucji prawnej przez wprowadzanie szczegółowych klauzul porządku publicznego (norm kolizyjnych wskazujących w określonych wypadkach właściwość wyłączną własnego prawa, a tym samym uchylając właściwość obcego prawa $)^{46}$, natomiast nie klauzul porządku publicznego sensu stricto. Ponadto, użycie przepisów, które są określone nieprecyzyjnie jako klauzule szczegółowe, nie wymaga powołania się na podstawowe zasady porządku

\footnotetext{
${ }^{44} \mathrm{~K}$. ZAWADA, Klauzula porzadku publicznego $w$ prawie prywatnym międzynarodowym, „Nowe Prawo" 1979, nr 4, s. 84.

45 Tamże.

${ }^{46}$ M. SoŚnIAK, Prawo prywatne, s. 87.
} 
prawnego, co jest charakterystyczne dla klauzuli, a ich zastosowanie nie powoduje wyłączenia klauzuli ogólnej, zawsze będącej do dyspozycji sędziego ${ }^{47}$.

Obecnie $\mathrm{w}$ prawie prywatnym międzynarodowym zanikają także szczegółowe klauzule porządku publicznego. Klauzula ta nabiera charakteru ogólniejszego, chroniącego zasady krajowe jedynie w szczególnie rażących przypadkach, dzięki czemu nie narusza zasad współpracy międzynarodowej ${ }^{48}$. Czasami ogólnemu, blankietowemu pojęciu porządku publicznemu towarzyszą pojęcia dobrych obyczajów lub zwyczajów ${ }^{49}$.

Abstrahując od powyższej genezy klauzuli porządku publicznego, trzeba zaznaczyć, że w okresie międzywojennym samo pojęcie porządku publicznego wywodzono z pojęcia prawa publicznego (ius publicum), czyli zbioru przepisów odnoszących się do ustroju państwa i jego władz, ich postępowania oraz właściwości. Porządek publiczny jest sferą chronioną, zastrzeżoną dla działań państwa, w którą podmiotom prywatnym przez ich działania nie wolno wkraczać. Tak też w tym czasie pojmowano pojęcie porządku publicznego w prawie administracyjnym, w którym m.in. wyznaczało ono strefę działania policji administracyjnej ${ }^{50}$.

Pojęcie to w Kodeksie Zobowiązań ${ }^{51}$ odnosiło się do zasadniczych podstaw istniejącego w państwie ustroju państwowego, ekonomicznego, społecznego, a ponadto podstawowych zasad ustroju społeczno-prawnego ${ }^{52}$.

Już w polskiej międzywojennej nauce powstał spór o charakter, a tym samym zakres tego pojęcia. Ludwik Domański stał przy stanowisku, że odwoływanie się do porządku publicznego w art. 55 Kodeksu Zobowiązań odsyłało do przepisów porządku publicznego. Z kolei przez przepisy porządku publicznego rozumiał on przepisy o charakterze publicznoprawnym, niezależnie czy umiejscowione $\mathrm{w}$ ustawach prawa prywatnego, czy też prawa publicznego. W art. 55 Kodeksu Zobowiązań rozróżniono ustawy i porządek publiczny. Jego zdaniem podział ten był nieścisły, ponieważ porządek publiczny może

\footnotetext{
${ }^{47}$ M. SoŚNIAK, Uwagi do projektu polskiego prawa prywatnego międzynarodowego, „Nowe Prawo" 1962, nr 7-8, s. 1013.

${ }^{48}$ M. SoŚnIAK, Prawo prywatne, s. 87.

${ }^{49}$ K. BAGAN-Kurluta, M. StuS, Stosowanie klauzuli porządku publicznego w Polsce w odniesieniu do europejskiego ustawodawstwa partnerskiego, „Kwartalnik Prawa Prywatnego” 2005, nr 1-2, s. 243-244.

${ }^{50}$ M. OlECHOwSKI, Porządek publiczny jako ograniczenie swobody umów, „Państwo i Prawo” 1999, nr 4, s. 61.

${ }^{51}$ Rozporządzenie Prezydenta Rzeczypospolitej z dnia 27.10.1933 r. - Kodeks Zobowiązań, Dz.U. z 1933 r., Nr 82, poz. 598.

${ }^{52}$ M. OlechowsKi, Porzadek publiczny, s. 61.
} 
być tylko ustawowy, natomiast zakaz sprzeciwiania się ustawie da się usprawiedliwić jedynie wtedy, gdy ma ona publicznoprawny charakter lub zawiera przepisy porządku publicznego. Proponował więc, żeby przez zakaz sprzeciwiania się ustawie rozumieć tylko zakaz sprzeciwiania się wyraźnym zakazom lub nakazom ustawowym, podczas gdy do przepisów porządku publicznego zaliczyć także postanowienia ustawowe mające na widoku interes społeczeństwa (ogółu) przed interesem jednostek ${ }^{53}$.

Natomiast Roman Longchamps de Bérier zauważył, że bezwzględnie obowiązujący charakter przepisu może wynikać z jego treści w przypadkach, gdy nie wynika z jego zakazującego czy nakazującego brzmienia, ale treść wskazuje m.in. na kontekst porządku publicznego. Ten przedstawiciel ówczesnej nauki przepisy o charakterze bezwzględnie obowiązującym, tj. ius cogens zaliczał jednak do kategorii ustawy z art. 55 Kodeksu Zobowiązań. Takie rozumienie pojęcia ustawy w tym ujęciu było czymś innym niż porządek publiczny. Z jego Uzasadnienia projektu Kodeksu Zobowiązań ${ }^{54}$ wynika, iż „nie zawsze umowa sprzeciwiająca się porządkowi publicznemu będzie zarazem sprzeczna z jakimś przepisem ustawy" ${ }^{\prime 5}$. W ramach pojęcia porządku publicznego zaliczał te spośród podstawowych zasad ustrojowych, które legislator nie musi wyrażać poprzez przepis skierowany do stron, a więc np. zakaz postanowień umownych nadmiernie ograniczających wolność osobistą. Jako przykłady naruszeń porządku publicznego na tle art. 55 Kodeksu Zobowiązań autor ten podawał m.in. sprzeczność z ustrojem sądowym, familijnym, obowiązkami obywatelskimi, równością wobec prawa i wolnością zarobkowania ${ }^{56}$.

W prawie arbitrażowym klauzula porządku publicznego funkcjonuje ze względu na wielostopniowe zapożyczenie, gdyż z prawa międzynarodowego prywatnego została przejęta do międzynarodowego postępowania cywilnego ${ }^{57}$, którego rozwiązania posłużyły następnie za wzór prawnej regulacji arbitrażu ${ }^{58}$.

53 Tamże.

54 Tamże.

${ }^{55}$ Biblioteka Uniwersytetu Wrocławskiego [dalej: BUWr] PAd 325560 II, R. LONGCHAMPS DE BÉRIER, Uzasadnienie projektu Kodeksu Zobowiązań, Warszawa: Wydawnictwo Urzędowe Komisji Kodyfikacyjnej 1934, z. 4, s. 72, https://bibliotekacyfrowa.pl/dlibra/publication/38921/edition /40516/content [dostęp: 6.10.2019].

${ }^{56}$ M. OlechowsKi, Porządek publiczny, s. 61-62. Do takiego ujęcia pojęcia porządku publicznego bezpośrednio odsyłał F. Zoll w: F. ZoLL, Zobowiąania w zarysie wedtug polskiego Kodeksu Zobowiązań, Warszawa: Nakł. Gebethnera i Wolffa 1945, s. 28.

${ }^{57}$ A.W. WIŚNIEWSKI, Klauzula porzadku publicznego jako podstawa uchylenia wyroku sądu arbitrażowego (ze szczególnym uwzględnieniem stosunków krajowego obrotu gospodarczego), „ADR. Arbitraż i Mediacja” 2019, nr 2(6), s. 120.

58 N. RycKo, Stosowanie klauzuli, s. 209. 
„Rozporządzenie Prezydenta Rzeczypospolitej z dnia 29.11.1930 r. - Kodeks Postępowania Cywilnego (Dz.U. 1930, Nr 83, poz. 651 ze zm.) zawierało klauzulę porządku publicznego zarówno w postępowaniu o stwierdzenie wykonalności wyroku sądu polubownego, jak i o uchylenia wyroku sądu polubownego"59. Obwieszczenie Ministra Sprawiedliwości z dnia 1.12.1932 r. w sprawie ogłoszenia jednolitego tekstu Kodeksu Postępowania Cywilnego (Dz.U. 1932, Nr 112, poz. 934) dokonało tylko zmian redakcyjnych tego kodeksu w zakresie klauzuli porządku publicznego ${ }^{60}$. W Kodeksie Postępowania Cywilnego dostosowanym do komunistycznych realiów PRL (Dz.U. 1950, Nr 43, poz. 394) pojęcie porządku publicznego zostało zastąpione określeniem praworządności, natomiast pojęcie dobrych obyczajów zostało zastąpione pojęciem zasad współżycia społecznego w Państwie Ludowym ${ }^{61}$.

\section{HISTORIA KLAUZULI PORZĄDKU PUBLICZNEGO W OKRESIE MIĘDZYWOJENNYM I W OKRESIE PRL W POLSKIM ORZECZNICTWIE}

Już w okresie międzywojennym polski SN pozostawił dorobek dotyczący klauzuli porządku publicznego. Sąd Najwyższy w orzeczeniu z dnia 6.05.1936 r., C I 1914/35, stwierdził, iż ,[...] prawodawca [...] przewiduje tylko w wyjątkowych wypadkach możność uchylenia wyroku sądu polubownego i przepisy te nie ulegają wykładni rozszerzającej, przeto Sąd państwowy nie jest władny wdawać się w rozpoznanie zarzutów co do pogwałcenia przepisów prawa materialnego lub przepisów ogólnych prawa formalnego, obowiązujących w postępowaniu sądowym, również nie ma prawa wchodzić $\mathrm{w}$ rozstrzygnięcie słuszności wyroku lub trafności ustaleń faktycznych i pobudek, na których wyrok został oparty". Obecnie orzeczenie to ma jedynie walor historyczny. Jest ono jednym z najstarszych, a jednocześnie jednym z najbardziej restrykcyjnych orzeczeń SN, które de facto czyniło tę instytucję prawną martwą ${ }^{62}$. W orzeczeniu tym SN wprost wskazał na istnienie materialnego i procesowego porządku publicznego. Także obecnie zarówno w praktyce, jak i doktrynie nie budzi wątpliwości podział klauzuli porządku publicznego na materialną

\footnotetext{
${ }^{59}$ K. RYSZKOWSKI, Klauzula procesowego porzadku publicznego, s. 73.

60 Tamże.

${ }^{61}$ Tamże, s. 73-74.

${ }^{62}$ Tamże, s. 3.
} 
i procesową, który jest odbiciem podziału prawa na część materialną i procesową ${ }^{63}$.

W orzeczeniu z dnia 8.02.1937 r., C III 1254/35, SN orzekł, iż „[...] należy uznać za słuszne zapatrywanie Sądu Apelacyjnego, że uchybienie porządkowi publicznemu lub dobrym obyczajom [...] mieścić się musi w treści samego orzeczenia, że nie wystarcza natomiast, aby zachodziło ono bądź to w składzie sądu polubownego lub też w postępowaniu przed tymże sądem”. Uchybienie w składzie sądu polubownego może ewentualnie uzasadniać inną podstawę uchylenia orzeczenia sądu polubownego ${ }^{64}$. Powyższe zapatrywanie SN bardzo zawężało możliwość kontroli orzeczenia sądu polubownego, a w szczególności poprzez wykluczenie z klauzuli porządku publicznego badania zgodności z nią składu sądu polubownego i postępowania przed nim. Obecnie dominuje stanowisko, wedle którego kontroli podlegają skutki, jakie wyrok sądu polubownego będzie miał dla krajowego porządku prawnego ${ }^{65}$.

Sąd Najwyższy w uchwale z dnia 3.04.1957 r., I CO 4/57, przyjął, że „,...] art. 509 i 510 § 1 pkt 4 k.p.c. zezwala na taką sytuację, w której sąd polubowny nie zastosuje obowiązującego prawa, nie czyniąc żadnego wyjątku ze względu na rodzaj stron. Gdyby zaś w rozstrzygnięciu swym dopuścił się naruszenia przepisów bezwzględnie obowiązujących lub zasad współżycia społecznego, to wyrok taki podlegałby uchyleniu (art. 509 i $510 \S 1$ pkt 4 k.p.c.)". W orzeczeniu tym SN utożsamia zatem praworządność z przepisami bezwzględnie obowiązującymi $^{66}$.

W wyroku z dnia 21.12.1973 r., I CR 663/73, SN stwierdził, iż mylnej „,[...] wykładni prawa materialnego przez sąd polubowny nie można ocenić jako uchybienia praworządności w rozumieniu art. $712 \S 1$ pkt 4 k.p.c. W szczególności nie można uważać za takie uchybienie zastosowania przez sąd polubowny przepisów o przedawnieniu lub prekluzji, choćby nastąpiło to na podstawie ich błędnej wykładni”. Na kanwie uchwały SN z dnia 3.04.1957 r., I CO 4/57, i wyroku SN z dnia 21.12.1973 r., I CR 663/73, w literaturze przedmiotu wyrażono pogląd, że doktryna usiłuje złagodzić zbyt sztywne ujęcie SN

\footnotetext{
${ }^{63}$ Tamże, s. 2.

${ }^{64}$ Ł. BŁaszczaK, M. Ludwik, Sadownictwo polubowne (arbitraż), Warszawa: C.H. Beck 2007, s. 286.

${ }^{65}$ A. SZCZĘŚNIAK, Funkcja klauzuli porządku publicznego i metoda kontroli zgodności wyroku sadu polubownego z porzadkiem publicznym RP, [w:] Ius est a iustitia appelatum. Księga jubileuszowa dedykowana Prof. Tadeuszowi Wiśniewskiemu, red. T. Ereciński, J. Gudowski, M. Pazdan, M. Tomalak, Warszawa: Wolters Kluwer 2017, s. 1172.

${ }^{66}$ K. RYSZKOWSKI, Klauzula procesowego porzadku publicznego, s. 73.
} 
i nie utożsamia uchybienia praworządności z naruszeniem przez sąd polubowny przepisów bezwzględnie obowiązujących. J. Łopuski przyjmował, że naruszenie prawa materialnego jedynie wtedy może stanowić uzasadnioną podstawę uchylenia orzeczenia sądu arbitrażowego, gdy skutkuje jawnym pogwałceniem naczelnych zasad obowiązujących w porządku prawnym Państwa Ludowego (PRL) ${ }^{67}$. Należy nadmienić, że jest to pogląd dominujący również obecnie (oczywiście biorący pod uwagę naczelne zasady prawne obecnego porządku prawnego) nie tylko odnośnie do naruszenia materialnego porządku publicznego, ale również procesowego porządku publicznego. Powyższe orzecznictwo wskazuje natomiast na kolejną powszechnie aprobowaną cechę klauzuli porządku publicznego, to jest wyjątkowość jej stosowania.

\section{WNIOSKI}

Analiza powyższych koncepcji wskazuje na co najmniej jeden punkt styczny pojęcia porządku publicznego. Pojęcie to pojawia się w sytuacjach sprzeczności interesu generalnego (powszechnego) z interesem partykularnym (indywidualnym). W takich wypadkach jest utożsamiane $\mathrm{z}$ interesem powszechnym, a nadto może spełniać dwie funkcje. Wyżej przytaczani przedstawiciele doktryny, na podstawie Kodeksu Zobowiązań, byli zgodni co do pierwszej funkcji, to jest kwalifikującej mocy wiążącej przepisów i norm prawnych. Porządek publiczny wypływający z treści przepisu lub normy wskazuje na moc takiego przepisu, która jest bezwzględnie obowiązująca. Nadto należy dodać, że w takich sytuacjach mamy do czynienia $\mathrm{z}$ oddziaływaniem pośrednim porządku publicznego na zakres swobody umów, jednak może on także wpływać w sposób bezpośredni. Na potrzeby takiego rodzaju oddziaływania przyjmuje się, że porządek publiczny jest równoznaczny z podstawowymi zasadami porządku prawnego w danym państwie. W jego skład wchodzą zatem zasadnicze podstawy ustroju ekonomicznego, społecznego i państwowego ${ }^{68}$, a także fundamentalne zasady prawa, zarówno materialnego, jak i procesowego.

Należy zauważyć, że również obecnie nie ma konsensu odnośnie do pojęcia i treści klauzuli porządku publicznego w arbitrażu handlowym, w szczegól-

${ }^{67}$ P. BALLADA, Zagadnienie obowiazku stosowania prawa materialnego w postepowaniu przed sądem polubownym, „Ruch Prawniczy, Ekonomiczny i Socjologiczny” 2002, nr 1, s. 98-99.

${ }^{68}$ M. Olechowski, Porzadek publiczny, s. 66. 
ności w zakresie stosunku pomiędzy klauzulą porządku publicznego a wspomnianymi wyżej dobrymi obyczajami vel zasadami współżycia społecznego ${ }^{69}$. Brak jednolitego rozumienia tej instytucji prawnej występuje nie tylko na gruncie polskim, ale również zagranicznym i międzynarodowym. Wykładnia historyczna okaże się bardzo przydatna dla ustalenia pojęcia oraz treści tej instytucji prawnej, gdyż bez zrozumienia korzeni tej instytucji prawnej nie da się określić jej obecnego kształtu i funkcji w arbitrażu handlowym.

\section{BIBLIOGRAFIA}

\section{ŹRÓDŁA PRAWA}

Kodeks Napoleona - Francuski kodeks cywilny (Code Napoléon, Code civil des Français), ustawa $\mathrm{z}$ dnia 21 marca $1804 \mathrm{r}$.

Rozporządzenie Prezydenta Rzeczypospolitej z dnia 29.11.1930 r. - Kodeks Postępowania Cywilnego, Dz.U. z 1930 r., Nr 83, poz. 651 ze zm.

Rozporządzenie Prezydenta Rzeczypospolitej z dnia 27.10.1933 r. - Kodeks Zobowiązań, Dz.U. z 1933 r., Nr 82, poz. 598.

Ustawa z dnia 17 listopada 1964 r. - Kodeks postępowania cywilnego, Dz.U. z 2019 r., poz. 1460.

\section{LITERATURA}

BAGAN-Kurluta Katarzyna: Prawo prywatne międzynarodowe, Warszawa: C.H. Beck 2006.

BAgAn-KuRluta Katarzyna, Stus Marek: Stosowanie klauzuli porządku publicznego w Polsce w odniesieniu do europejskiego ustawodawstwa partnerskiego, „Kwartalnik Prawa Prywatnego" 2005, nr 1-2, s. 227-252.

BALLADA Przemysław: Zagadnienie obowiązku stosowania prawa materialnego w postępowaniu przed sądem polubownym, „Ruch Prawniczy, Ekonomiczny i Socjologiczny” 2002, nr 1, s. 87-103.

BŁaszczaK Łukasz, LudwIK Małgorzata: Sądownictwo polubowne (arbitraż), Warszawa: C.H. Beck 2007.

CzEPELAK Marcin: Umowa międzynarodowa jako źródło prawa prywatnego międzynarodowego, Warszawa: Wolters Kluwer Polska 2008.

GILAS Janusz: Prawo prywatne międzynarodowe, Warszawa: Wydawnictwo Prawnicze LexisNexis 2002

JAKUBOwSKI Jerzy: Prawo międzynarodowe prywatne. Zarys wykładu, Warszawa: Państwowe Wydawnictwo Naukowe 1984.

KAHN Franz: Abhandlungen zum internationalen Privatrecht, München: Verlag Duncker \& Humblot 1928

\footnotetext{
${ }^{69} \mathrm{~K}$. RYSZKOWSKI, Klauzula porządku publicznego jako klauzula generalna $w$ arbitrażu han-
} dlowym w prawie polskim, „Przegląd Prawa Handlowego” 2014, nr 3, s. 19. 
LONGCHAMPS DE BÉRIER Roman: Uzasadnienie projektu Kodeksu Zobowiązań, Warszawa: Wydawnictwo Urzędowe Komisji Kodyfikacyjnej 1934, BUWr PAd 325560 II, https://biblioteka cyfrowa.pl/dlibra/publication/38921/edition/40516/content [dostęp: 6.10.2019].

NowACZYK Piotr: Sąd Arbitrażowy przy KIG na tle innych instytucji arbitrażowych, Court of Arbitration at the Polish Chamber of Commerce compared to other arbitral institutions, „Biuletyn Arbitrażowy" 2008, nr 7, s. 64-67.

OleChOwSKi Marcin: Porządek publiczny jako ograniczenie swobody umów, „Państwo i Prawo” 1999, nr 4, s. 60-72.

PAZDAN Maksymilian: Prawo prywatne międzynarodowe, Warszawa: Wydawnictwo Prawnicze LexisNexis 2012.

RYCKO Nikodem: Stosowanie klauzuli porządku publicznego przez Polski Sąd Państwowy w sprawach dotyczących arbitrażu (Prace laureatów konkursu na najlepszą pracę magisterską dotyczącą problemów sądownictwa polubownego i mediacji im. prof. dr. hab. Jerzego Jakubowskiego), edycja piąta, Warszawa: C.H. Beck 2012, s. 197-243.

RYSZKOWSKI Karol: Klauzula porządku publicznego jako klauzula generalna w arbitrażu handlowym w prawie polskim, „Przegląd Prawa Handlowego” 2014, nr 3, s. 17-20.

RYSZKOWSKI Karol: Klauzula procesowego porządku publicznego w arbitrażu handlowym w prawie polskim na tle innych systemów prawnych, Warszawa: C.H. Beck 2019.

RYszKowski Karol, Prokocki Piotr: Losy prawa rzymskiego na Wschodzie od śmierci Justyniana Wielkiego do upadku Cesarstwa Bizantyjskiego, „Edukacja Prawnicza” 2020, nr 1, s. 11-16.

SoŚNIAK Mieczysław: Klauzula porządku publicznego w prawie międzynarodowym prywatnym, Warszawa: Państwowe Wydawnictwo Naukowe 1961.

SoŚNIAK Mieczysław: Prawo prywatne międzynarodowe, Katowice: Wydawnictwo Uniwersytetu Śląskiego 1991.

SoŚNIAK Mieczysław: Uwagi do projektu polskiego prawa prywatnego międzynarodowego, „Nowe Prawo" 1962, nr 7-8, s. 1110-1119.

SOŚNIAK Mieczysław, WALASZEK Bronisław: Zarys prawa prywatnego międzynarodowego, Warszawa: Państwowe Wydawnictwo Naukowe 1973.

SZCZĘŚNIAK Alicja: Funkcja klauzuli porządku publicznego i metoda kontroli zgodności wyroku sądu polubownego z porządkiem publicznym RP, [w:] Ius est a iustitia appelatum. Księga jubileuszowa dedykowana Prof. Tadeuszowi Wiśniewskiemu, red. Tadeusz Ereciński, Jacek Gudowski, Maksymilian Pazdan, Michał Tomalak, Warszawa: Wolters Kluwer 2017, s. 1165-1178.

WIŚNIEWSKI Andrzej W.: Klauzula porządku publicznego jako podstawa uchylenia wyroku sądu arbitrażowego (ze szczególnym uwzględnieniem stosunków krajowego obrotu gospodarczego), „ADR. Arbitraż i Mediacja” 2019, nr 2(6), s. 119-131.

ZACHARIASIEWICZ Maciej: Klauzula porządku publicznego jako instrument ochrony materialnoprawnych interesów i wartości fori, Warszawa: C.H. Beck 2018.

ZAWADA Kazimierz: Klauzula porządku publicznego w prawie prywatnym międzynarodowym, „Nowe Prawo” 1979, nr 4, s. 71-84.

ZIELIŃSKI Marcin: Klauzula porządku publicznego przy uznawaniu i wykonywaniu wyroków w międzynarodowym arbitrażu handlowym w świetle systemów prawnych Polski, Niemiec, Szwajcarii, oraz porządku prawnego Unii Europejskiej (Prace laureatów konkursu na najlepszą pracę magisterską dotyczącą problemów sądownictwa polubownego i mediacji im. prof. dr. hab. Jerzego Jakubowskiego), Warszawa: C.H. Beck 2003, s. 229-286. 
ZoLL Fryderyk: Zobowiązania w zarysie według polskiego Kodeksu Zobowiązań, Warszawa: Nakł. Gebethnera i Wolffa 1945.

\section{RYS HISTORYCZNY KLAUZULI PORZADKU PUBLICZNEGO W ARBITRAŻU HANDLOWYM W PRAWIE POLSKIM DO OKRESU PRL WŁĄCZNIE}

$$
\text { Streszczenie }
$$

Klauzula porządku publicznego jest nierozerwalnie związana z sądownictwem arbitrażowym. Wyrażono pogląd, że sądownictwo polubowne, a tym samym klauzula porządku publicznego, jest tak stare jak historia ludzkości oraz znacznie starsze od sądownictwa powszechnego. Zarówno sądownictwo arbitrażowe, jak i instytucja klauzuli porządku publicznego były już znane w starożytnych systemach prawnych. Początek naukowej refleksji nad klauzulą porządku publicznego związany jest z początkami międzynarodowego prawa prywatnego. Należy zauważyć, że również obecnie nie ma konsensu odnośnie do pojęcia i treści klauzuli porządku publicznego w arbitrażu handlowym. Brak jednolitego rozumienia tej instytucji prawnej występuje nie tylko na gruncie polskim, ale i międzynarodowym. Wykładnia historyczna okaże się bardzo przydatna dla ustalenia pojęcia oraz treści tej instytucji prawnej, gdyż bez zrozumienia korzeni tej instytucji prawnej nie da się określić jej obecnego kształtu i funkcji w arbitrażu handlowym.

Słowa kluczowe: klauzula porządku publicznego; arbitraż; postępowanie arbitrażowe; prawo prywatne międzynarodowe

HISTORICAL OUTLINE OF THE PUBLIC POLICY CLAUSE IN THE COMMERCIAL ARBITRATION IN POLISH LAW UP TO THE PRL PERIOD

\section{S u m m a r y}

The public policy clause is inherently related to arbitration. The opinion was expressed that arbitration, and thus a public policy clause, is as old as humanity and much older than state courts. This institution already exists in ancient legal languages. The beginning of scientific reflection on the public policy clause is related with the beginnings of private international law. It should be noted that there is currently no consensus on the concept and content of the public policy clause in commercial arbitration. The lack of a uniform understanding of this institution exists not only in Poland but also in general. A historical interpretation will prove to be very useful to determine the concept and content of this institution, because without the understanding of the roots of this institution's functions there is not possibility to understand its current functions in the commercial arbitration.

Keywords: public policy clause; arbitration; arbitral tribunal; arbitration proceedings; private international law 